\title{
The Vulnerability of Women in Dealing with Covid-19 Pandemic: Feminist Legal Theory Approach
}

\author{
Linda Sudiono \\ Faculty of Law, Universitas Atma Jaya Yogyakarta, Indonesia; Doctoral Student, Faculty of Law, \\ Justus-Liebig-Universität Giessen, Germany.E-mail: lindasd@uajy.ac.id
}

\begin{abstract}
Women are one of the community groups most affected by Covid-19 because most are workers with lower incomes and unprotected financial security. Moreover, most women occupy the informal sector, which is more vulnerable in accessing social security guarantees. In addition, domestic violence against women increases in several countries during the pandemic. This article aims to analyze the causes of the negative impacts of the Covid-19 pandemic on Women and formulate the legal solution using the Feminist Legal Theory approach. The results show that there are broadly two causes of negative impacts for women dealing with Pandemic Covid-19. Firstly, due to the inequality in economic structure. Secondly is the gender stigmatized social structure. In this case, the feminist legal theory approach can be used to reconstruct and reform the negative impacts, as well as reanalysis the solutions in realizing women's legal justice due to the outbreak of the covid-19 pandemic. This study offers three solution methods. Firstly, analyzing the legal methods in giving gender implications and perpetuating women's subordination. Secondly, making gender the main category in conducting legal analysis. Thirdly, considering gender specificity in achieving legal equality for women.
\end{abstract}

Keywords: Covid-19; Equality; Feminist Legal Theory; Justice; Women

\section{Introduction}

The pandemic of Covid-19. has deepened pre-existing inequalities, revealing the vulnerability of gender-based social, political, and economic systems, which in turn broadens the impact of this pandemic. This further clarifies the interlocking economic, social and political crises, especially against the most marginalized communities. According to preliminary data released by the International Labor Organization (ILO), there will be an increase in global unemployment between 5.3 million and 25 million as a result of Covid-19. This increase in unemployment will be followed by the consequences of loss of income and social protection, as well as an increase in poverty. ${ }^{1}$ This figure is higher than the financial crisis in 2008-2009 with the unemployment rate reaching 22 million. ${ }^{2}$

\footnotetext{
1 "Covid-19 and the World of Work : Impact and Policy Responses," International Labor Organization, last modified March 18, 2020, https://www.ilo.org/wcmsp5/groups/public/---dgreports/--dcomm/documents/briefingnote/wcms 738753.pdf.

2 International Labor Organization, "Policy Responses."
} 
Women are one of the entities most affected by Covid-19. Around the world, women have a predisposition to take lower paying job and less of access to long-term financial security. Women occupy the informal sector which is more vulnerable in access to social security guarantees. This causes the covid-19 pandemic to have unpleasant effects on women. The impact of the poor management of this Pandemic deepens pre-existing inequalities, revealing the vulnerability of gender-based social, political, and economic systems, which in turn broadens the impact of this pandemic. This further clarifies the interlocking economic, social, and political crises, especially against the most marginalized communities. The emerging of crisis due to covid-19 pandemic outbreak has resulted substantially increase of the unrecognized unpaid care-work burden for women, which is the main support for the economy. Kate power argues that there should be a systemic change to value the burden of unpaid care work done by women in economic and social policies. ${ }^{3}$ Similar to Power, Carli highlights that the outbreak has impacted on the raising of challenges should be gone through by woman in work force.

The pandemic outbreak has caused more women losing their work or infected in the essential jobs. Moreover, increasing of childcare and others domestic chores caused by the closure of school and public services have disrupted more women than man. Notwithstanding, Work from Home (WFH) policy implied to reduce the spreading of the virus has potentially enlarge the chance for man to take the responsibility in domestic works. ${ }^{4}$ Furthermore, gender-based violence shows an alarming increase during the outbreaks. Mittal and Singh emphasize the covid-19 pandemic outbreak impact on the surge of gender-based violence. The increasing cases of gender-based violence has emerged an apprehension of women safety. Instead of coping with this issue, legislature measure taken by government has failed to protect women's safety, while the required service has been provided by couple of non-government organizations precisely. ${ }^{5}$

This article discusses the causes and effects of women's vulnerability in dealing with the co-19 pandemic from Feminist Legal Theory approach. The first part of this article provides the analyses of the negative impacts causes on women in dealing with covid-19 pandemic. This part deals with two causes namely the inequality due to the economic structure and the negative impacts due to the stigmatized gender identity in the social structure. Some practical implications are drawn in the last section.

\section{Vulnerability of Women in Facing Pandemic Covid-19}

Broadly speaking, there are two causes of negative impacts for women in dealing with Covid-19 pandemic. Firstly, women's vulnerability due to inequality in economic structures. The discourse of globalization was first introduced to the world shadowed by the expectations of equitable forms of development. Some theories have begun to explain the goodness of globalization economically which gives an idea of the new world.

\footnotetext{
3 Kate Power, "The COVID-19 pandemic has increased the care burden of women and families," Sustainability: Science, Practice and Policy 16, no. 1 (2020): 70-71

${ }^{4}$ Linda L. Carli, "Women, Gender equality and COVID-19," Gender in Management 35, no. 7 (2020): 653655

${ }^{5}$ Shalini Mittal and Tushar Singh, "Gender-Based Violence During COVID-19 Pandemic: A Mini-Review," Frontiers in Global Women's Health 1, no. 4 (September 2020): 3-5
} 
Nigel Harris welcomed economic globalization by saying that the invisible hands of globalization would erode the differences in third and first world countries because it allows producers to compete freely. This free trade competition will trigger the opening of new investment in remote areas with an abundance of natural resources and cheap labor so that the dependence on the means of production will continue to be eroded. This utopian expectation is what he mentions as the full prospect of economic equality. ${ }^{6}$

The globalization has proven to eliminate the world's distance, through the advancement of transportation, communication and trade regulation. The loss of national boundaries encourages the creation of a uniquely and harmonious acculturation. However, besides the advantages that been explained, globalization has also contributed to enlarging the economic capacity gap between developed and developing countries. ${ }^{7}$ This condition also influenced the ability of the State to deal with the Covid-19 pandemic. The relatively unprotected economic gates, the accessible of cheap labor, the low scales of purchasing power, the high rates unemployment, are considered to be some of the causes of the Global South's vulnerability, including Indonesia, in facing the economic crisis derived from the Covid-19 pandemic. The loss of state power over natural resources due to the privatization of planned natural resources is also alleged to be the basis of Indonesia's dependence on economic vulnerability and fluctuations due to the pandemic crisis.

The sustainability of this condition will be the background of labor surplus (increasing unemployment and wages that are not equivalent to prices). It generates a decrease in people's purchasing power and as a consequence is allegedly able to create an economic crisis, precipitating overproduction of commodities circulating in the market, and capital surpluses (abundance of commodities, financial surpluses that lose new productive investment channels). The countries with protected financial markets tend to be protected from speculative currents compared to the countries with liberalized capital markets. The differences are crucial that will determine state risks in encountering devaluation. $^{8}$

One inevitable consequence is the widespread scale of the world economic crisis due to the pandemic. The constant efforts are diversion of investment into long-term infrastructure projects, social investment to create labor competitiveness and increasing state purchasing power and / or market expansion to find new resources, new production capacity and new sources of cheap labor. ${ }^{9}$ To deal with this issue, international financial institutions will tend to disburse credit systems for social loan funds to save long-term decline in social capacity that affects changes in policies and institutional arrangements to ensure economic growth and avoid a balance of payments crisis. ${ }^{10}$ Regarding to the

\footnotetext{
${ }^{6}$ Nigel Harris, The End of Third World: Newly Industrializing Countries and the Decline of an Ideology (Harmondsworth: Penguin, 1986), 38.

7 Fairooz Mustafa Hamdi, "The Impact of Globalization in Developing Country," Developing Country Studies 3, no. 11 (2013): 142-44.

8 David Harvey, Imperialisme Baru (Yogyakarta: Resist Book, 2010), 21.

${ }^{9}$ David Harvey, Imperialisme Baru, 18.

10 Henry Veltmeyer, James Petras, and Steve Vieux. Neoliberalism and Class Conflict in Latin America: A Comparative Perspective on the Political Economy of Structural Adjustment (London: Macmillan press, 1997), 59.
} 
global impact of the co-19 pandemic, the World Bank and International Monetary Fund (IMF) released a policy in the form of emergency loans aimed specifically at sluggish economy state and developing countries.

However, emergency loans that disbursed are not unconditional. Major role played by multinational financial institutions -World Bank, IMF, etc.- in shaping the national policies through emergency loan followed by structural adjustment policies has critical impacts on the state independency. ${ }^{11}$ Health service facilities, public utilities and other essential services such as education and water have been targeted as profitable commodities through privatization policy, followed by an advanced deregulation policies. ${ }^{12}$ This credit system will in turn trap developing countries in extended debt and voluntarily lessen domestic market protection. It led to sluggish economy state increasingly entangled in the debt chains. Based on this analysis it can be recognized the reasons behind the World Bank's Executive Board's approval of two new projects worth USD700 million for Indonesia in dealing with the impact of the corona virus outbreak. The two projects are additional funding for assistance in the reform program and additional funding for reform policies in the development of the financial sector. ${ }^{13}$

A study conducted by the Center on Wisconsin Strategy in 2002 on Why Privatizing Government Services Would Hurt Women Workers shows that privatization of public utilities brings disadvantages status of workers, especially for those whose jobs are classified as low-end occupations. Vulnerable groups, including women who work in the low-income sector, will receive a negative impact from the privatization policy due to an increase in the cost of providing critical social services. In Asian countries, women are source of cheap labor, especially in export-oriented manufacturing industries, both formal and informal, who experience the most exploitation during the adjustment and / or restructuring process that is dominated by privatization. ${ }^{14}$ Among these vulnerabilities, gender inequality that already exists in society contributes to exacerbate the impact experienced by women. ${ }^{15}$ Pandemic Covid-19 has triggered an increase in unemployment and this condition is disproportionately disadvantages for women than men. ${ }^{16}$ The disproportionately effect of this pandemic on women are caused by the fact that women tend to occupy work positions in the industries most affected by this public health crisis,

\footnotetext{
11 Susan Strange, "The New World of Debt," New Left Review 230, no. 1 (August 1998): 91-114.

12 "Covid-19 Highlights the Failure of Neoliberal Capitalisme: We Need Feminist Global Solidarity," Asia Pasific Forum on Women, Law, and Development, last modified March 25, 2020, http://apwld.org/covid19-highlights-the-failure-of-neoliberal-capitalism-we-need-feminist-global-solidarity/.

13 "Bank Dunia Kucurkan Pinjaman 700 Juta Dollar AS untuk Indonesia," Kompas, last modified May 17, 2020, http://money.kompas.com/read/2020/05/17/160100526/bank-dunia-kucurkan-pinjaman-700-jutadollar-as-untuk-indonesia?page=2.

14 Ross Prizzia, "An International Perspective of Privatization and Women Workers," Journal of International Women's Studies 7, no. 1 (November 2005): 55-68.

15 Scott Horsley, "Women are losing more job in coronavirus shutdowns," National Public Radio, last modified April 8, 2020, https://www.npr.org/2020/04/08/829141182/women-are-losing-more-jobs-incoronavirus-shutdowns.

16 Pedro Nicolaci La Costa, "Coronavirus Unemployement Tsunami Hitting Women Harder-and It Could Cause Prolonged Damage," Forbes, last modified April 18, 2020, https://www.forbes.com/ sites/pedrodacosta/2020/04/18/coronavirus-unemployment-tsunami-hitting-women-harder-and-itcould-cause-prolonged-damage/?sh=5f8d58d25dd7.
} 
for example servants, child care workers, hairdressers, hotel maids, household assistants. These sectors are predicted to have experienced the biggest surge in unemployment since the Great Depression crisis of 1930. ${ }^{17}$

Economic instability is undoubtedly a gender issue with the influence of the cultural assumption which underpin women gender sex-role stereotype. This stereotype assumption encompasses lower appreciation of both paid and unpaid work carried out by women, and other forms of stigmatization. These factors have contributed to the discriminatory experience of women socially and economically. ${ }^{18} \mathrm{~A}$ world survey on the Role of Women in Development conducted by the United Nations in 2009 recognized that the global financial and economic crisis had become a serious global threat, as well as having a serious impact on women due to cutting health and education subsidies and increasing the risk caused by reducing the allocation of women's empowerment. Unequal access to resources has limited women's capacity for agricultural productivity, guarantees of livelihoods and food, which ultimately forms a chain of poverty, migration, urbanization and increases the risk of violence against women. ${ }^{19}$

Data from the International Labor Organization (ILO) shows that in 2018, women are at 26 percentage points less to work than men. The difference in the proportion of adult women with children under six years of age, compared with women without young children, increased significantly, by 38 percent. ${ }^{20}$ In addition, during the last 30 years, there is no significant changes found in the number of women occupying underrepresented and under-influential work positions.

In addition, gender gaps in labor market participation are extensive in the Arab, North African and South Asian countries. It is estimated that the basis for the limited access to gender-based labor is a cultural norm that restricts women's access and choice to get paid job. In developing countries shows the highest level of female labor participation (69.3 percent), but most are dominated by informal work which is 4.6-7.8 percentage points higher than men. ${ }^{21}$ This gender gap is higher in some sub-Saharan African countries, where it reaches more than 20 percentage points. In almost one third of SubSaharan countries, women are working in the informal non-agricultural sector account for more than 90 percent. ${ }^{22}$ This often reflects the economic need to find work, increased

\footnotetext{
17 Samantha Schimidt, "Women Have Been Hit Hardest by Job Losses in The Pandemic. And It May Only Get Worse," The Washington Post, last modified May 9, 2020, https://www.washingtonpost.com/dc-mdva/2020/05/09/women-unemployment-jobless-coronavirus/.

18 Postmus J.L. et,al., "Economic Abuse as an Invisible Form of Domestic Violence : Multicountry Review," Trauma, Violence, \& Abuse 21, no.2 (March 2018) : 261-83.

19 United Nation Department of Economic and Social Affairs, 2009 World Survey on The Role of Women in Development: Women's Control Over Economic Resources and Access to Financial Resources including Microfinance (New York: United Nation, 2009), 5, https://www.unwomen.org/sites/ default/files/Headquarters/Media/Publications/UN/en/WorldSurvey2009.pdf.

20 "The Women at Work Initiative," International Labor Organization, accessed May 5, 2020, https://www.ilo.org/global/about-the-ilo/history/centenary/WCMS 480301/lang--en/index.htm.

21 International Labor Organization, World Employment Social Outlook: Trend for Women 2018-Global Snapshot (Geneva: International Labor Office), 10, https://www.ilo.org/wcmsp5/groups/public/--dgreports/---dcomm/---publ/documents/publication/wcms 619577.pdf.

22 International Labor Organization, Trend for Women 2018, 10.
} 
poverty and lack of access to social protection. The data also shows that women receive salaries $20 \%$ lower than men. This gap is caused by the dominance of women in the lowpaid employment sector, as well as the weakness of institutions and policies that function to provide protection to workers, for example in terms of minimum wage policies. ${ }^{23}$ This is inversely proportional to the unemployment rate of women, which in 2018, showed 6 percent, 0.8 percent higher than men. This data also reflects the complexity of informal work and the restricted access to social security guarantee that contributes to encouraging workers to accept any work without questioning working conditions. ${ }^{24}$ Furthermore, women occupy $70 \%$ of the health and social services sector who have a higher risk of the Covid-19 pandemic. ${ }^{25}$

The country's economic growth rate is one factor that can be used to explain variations in women's involvement in the public. As the basis of the society structure, economic relations dialectically affect the reproduction of the superstructure in social formation, which in turn is a perpetuation of women's productivity levels, and provides a basis for the perpetuation of women's exclusion within the patriarchal culture framework. This situation has a worst impact on developing countries because the majority of women workers are informal sector workers with limited social security guarantees.

Generally informal jobs that mostly occupied by women are associated with public spaces and social interactions, for example freight workers in traditional markets, street traders, daily casual workers. ${ }^{26}$ In the midst of the Covid-19 pandemic, which requires restrictions on physical and social distance, causes women who work in the informal sector to experience significant economic impacts and the consequent loss of income to sustain the living expenses. ${ }^{27}$ Domestic workers, for example, according to data from the ILO in 2015 showed that there were 11.5 million Domestic Workers worldwide that were dominated by $70 \%$ of women. ${ }^{28}$ The ILO Director for Indonesia and Timor Leste, Michiko Miyamoto, said that Domestic workers are one of the worst employment sector in the world because of the prolonged working hours and mostly without legal protection governing working load, working hours and social security. ${ }^{29}$ Data from Jala PRT shows that the average wages of domestic workers is only around $20-30 \%$ of the minimum wages. ${ }^{30}$ This results women informal worker are vulnerable to be dismissed without compensation, vulnerable to poverty and potentially experiencing domestic violence due to depressed social unrest caused by policies of social restrictions and economic vulnerability.

\footnotetext{
23 International Labor Organization, Trend for Women 2018, 11.

24 International Labor Organization, Trend for Women 2018, 7.

25 "Neoliberal Capitalisme."

26 Social Affairs, including Microfinance.

27 Tarigan, Muhammad Insan, and Raisha Hafandi. "Equal Access to the Vaccination of Covid-19 in Southeast Asia: Can ASEAN be a Catalyst?." Hasanuddin Law Review 7, no. 2 (2021): 119-132.

28 Maria Galloti, "Migrant Domestic Workers Across the World: Global and Regional Estimates," International Labor Organization, accessed April 30, 2020, https://www.ilo.org/wcmsp5/groups/public/--ed protect/---protrav/---migrant/documents/briefingnote/wcms 490162.pdf.

29"Mempertanyakan Peran Negara atas Nasib PRT," Kumparan, accessed August 9, 2019, https://kumparan.com/kumparannews/menggugat-negara-sebagai-pelaku-kekerasan-terhadap-prt.

30 Kumparan, "Nasib PRT."
} 
Secondly is women's vulnerability due to stigmatized gender identity in social structures. Most of states have initiated pandemic control measures with \#stayathome slogan to reflect adherence of WHO recommendations. This is viewed as one of the effective solutions in preventing the spread of the Covid-19 virus. Unfortunately, this solution could mean a new crisis for others, including women. Strict limitation of outdoor movement to stop the spread of coronaviruses causes domestic violence has increased both in terms of intensity and severity. The United Nations has called for emergency action to counter the escalation of domestic violence, by calling on member States to prioritize women's security in formulating a policy response to a pandemic. In Spain, emergency services for domestic violence received $18 \%$ increasing calls since the adoption of the lockdown policy. In France, cases of "intimate terrorism" increased by 30\%. ${ }^{31}$ In South Africa the authorities received as many as 90,000 reports of violence against women in the first week of lockdown policy implementation. The UN reported that in Lebanon and Malaysia, help lines call received double increasing reports of domestic violence than a previous year, and similar reports increased triple in China. Google reports $75 \%$ increasing in online searches for assistance of domestic violence. ${ }^{32}$ In Indonesia, during the period of March 16-19 April 2020, since government launches call for outdoor movement restrictions, Legal aid of Indonesia Women Association for Justice (LBH APIK) received 97 complaints of violence against women. 1/3 of the total cases are domestic violence.

According to the 2016 National Women's Life Experience Survey (SPHPN), women who have unemployed husbands are at risk 1,36 times more likely to experience physical and /or sexual violence compared to those with employed spouse. ${ }^{33}$ This condition is exacerbated by the existence of a co-pandemic which causes women to have less choices to leave the house and/or establish economic independence. ${ }^{34}$ The high rate of violence against women can be analyzed through 2 aspects. First is the historical aspect and second is the cultural aspect.

Firstly, historical research shows that primitive societies had practiced equal social and sexual relations and characterized by collective production as well as communal property. ${ }^{35}$ Domestication of animals and the development of food preservation allowed the accumulation of private wealth inducing shifting on the mode of communal property

\footnotetext{
${ }^{31}$ Amanda Taub, "A new Covid-19 Crisis : Domestic Abuse Rises Worldwide," The New York Time News, last modified April 6, 2020, https://www.nytimes.com/2020/04/06/world/coronavirus-domesticviolence.html.

32 Scott Neuman, "Global Lockdown Resulting in 'Horrifying Surge,' in Domestic Violance, U.N. Warns," last modified April 6, 2020, https://www.npr.org/sections/coronavirus-live-updates/ 2020/04/06/827908402/global-lockdowns-resulting-in-horrifying-surge-in-domestic-violence-u-n-warns.

33 "Perempuan Rentan Jadi Korban KDRT, Kenali Faktor Penyebabnya," Kemenpppa, last modified May 19, 2018, https://www.kemenpppa.go.id/index.php/page/read/31/1742/perempuan-rentan-jadi-korbankdrt-kenali-faktor-penyebabnya.

34 "The Pandemic Maybe Making Domestic Abuse Worse," The Economist, last modified May 9, 2020, https://www.economist.com/international/2020/05/09/the-pandemic-may-be-making-domestic-abuseworse.

35 Hannah Devlin, "Early Men and Women Were Equal, Say Scientists," last modified May 14, 2015, https://www.theguardian.com/science/2015/may/14/early-men-women-equal-scientists.
} 
in the clan to private property in the family. ${ }^{36}$ The transformation of wealth control had consequence in changing gender relations in clan society. ${ }^{37}$ Women began to be converted into commodities in producing offspring as labor forces with the aim of maximizing wealth accumulation. In certain cases, women were exchanged in intertribal marriage practice. ${ }^{38}$ Women in this stage were deprived of control over the main food production and household of the clan. Patriarchal culture arose from these processes of women exclusion as a historical process. Furthermore, the exclusion of women takes place in 4 processes, namely negative stereotyping of women; subordinating the inferior role of women as second-class citizens; marginalizing women economically; preserving double burden for working women; and maintaining violence against women, both physical, verbal, sexual, psychological. ${ }^{39}$

Secondly, a system dominated by markets and profits has created a veil of alienation and mystification of the helplessness and surrender of self-fragmentation on the production within hierarchical system that is taken for granted. As if, this hierarchical system provides the "rights" for someone to treat subordinates in the hierarchy as objects, as he is also treated in the power relations formed by the system. The vulnerable, (including women) who are reduced of their rights and choices, have been subjected to the domination and impingement of alienation. ${ }^{40}$ The efforts to dominate the inferiors (making them targets for venting frustration, disappointment, despair) are seen as a form of reasonable and understandable control.

Women who are from lower economic capacity household tend to have a higher risk of experiencing domestic violence. They are from the family in the $25 \%$ poorest category have a 1.4 times higher risk of experiencing domestic violence than the same percentage of the richest families. ${ }^{41}$ Dominance through violence is not a result of individual dysfunctional, yet caused by the system that allowing some people to play an oppressive dominate role in the hierarchy to others. ${ }^{42}$ The family is always identified as the domain of male domination as the head of the household. In this secret full area of privacy, mystification of the alienation is canalized, forming a veiled of subjugation based on power relations. The cultural construction that disposes women as inferior second-class citizens exacerbates women stigmatize as "objects" of the impingement on resentment, disappointment, hopelessness and frustration generated by the co-19 pandemic and its derivative impacts in the form of economic crises, increased unemployment, limited access to social security, and increased poverty. It generates domestic violence against

\footnotetext{
36 Pat Brewer, The Dispossession of Women (Chippendale: Resistance Book, 2000), 13.

${ }^{37}$ Brewer, Dispossession of Women, 22.

38 Frederick Engels, Asal-Usul Keluarga, Kepemilikan Pribadi, dan Negara (Jakarta: Kalyanamitra, 2004), 64.

${ }^{39}$ Ayu Kusumastuti, "Rural Infrastructure and Gender Inequality in Agribusiness Development (A Case of Batu, East Java Province, Indonesia," in food security and food safety for the twenty first century, ed. Soraj Hongladarom (Bangkok: Department of Philosophy and Center for Ethics of Science and Technology Chulalongkorn University, 2015), 65-83.

40 Sandra Bloodwort, "The Roots of Sexual Violence," Marxis Left Review, accessed May 8, 2019, https://marxistleftreview.org/articles/the-roots-of-sexual-violence/.

41 Kemenpppa, "Kenali Faktor Penyebabnya."

42 Bloodwort, "Sexual Violence."
} 
women and seen this typical of violence as a reasonable and acceptable phenomenon. The oppressive domination that relates on the area of privacy, through domestic violence and sexual harassment, is acknowledged as the most traumatic form of subjugation that is able to disable potency and strength of subordinates who under the control. ${ }^{43}$

\section{Vulnerability of Women in Crisis: Feminist Legal Theory Approach}

The stereotype of women as duty-bearers of unpaid care-related work in the domestic household has been recognized as one of the triggers for subordinate inequality. This has a direct relationship to unequal wages, lower income, restricted access to education, and increasing the chance for women to be subjected to victims of violence. ${ }^{44}$ The co- 19 pandemic has exacerbated existing inequality conditions, especially in developing countries that consisted of $70 \%$ of women workers in the informal sector. ${ }^{45}$ This inequality was revealed obviously since call for "lock-down" has to be implemented to diminish the spread of pandemic. Economic pressure, social and cultural vulnerability and restricted of outdoor movement contribute to the spiking of gender-based violence. ${ }^{46}$ This means, women are not prepared by the system to deal with crisis situations. This condition is exacerbated by limited access to facilities and social security protection for the middle to lower income households. The vulnerability of women in dealing with the effects of the co-19 pandemic reflects the existence of established values and orders that have been unequal. One method that can be used to prove this thesis is to explore the legal values which are always serve as the highest symbol of the construction of consciousness representation adhered to by a particular social order. ${ }^{47}$ At the same time, pandemic covid-19 has arising awareness of the need for rapid legal changes by considering causality with regard to various sectors in the society. ${ }^{48}$

Gender-based violence is a phenomenon embedded in women's inequality that deeply involves social and cultural dimensions in identifying the hidden meaning on justified actions in supporting violence against women and limiting women's choices. For instance, domestic violence is always posited as a personal issue to be handled by social welfare workers, not by the general justice system. When this problem is positioned as a personal issue, the tendency is to blame the victim (wife) as inability of the wife as the person responsible for the household in maintaining the balance of values and functions of the family. Therefore, the prevention is evaluating the behavior of the wife to cope the domestic violence issue. ${ }^{49}$ In many cases, women who experience harassment from intimate partners are forced to leave the house because they don't have the ownership

\footnotetext{
43 Bloodwort, "Sexual Violence."

${ }^{44}$ Social Affairs, including Microfinance, 10.

45 Social Affairs, including Microfinance, 4.

46 Social Affairs, including Microfinance, 2.

47 Janet Rifkin, "Toward A Theory of Law and Patriarchy," in Source Book on Feminist Jurisprudence, ed. Hilaire Barnett, (Great Britain: Cavendish Publishing, 1997), 25.

48 Sara C. Bronin, "What the Pandemic Can Teach Climate Attorney," Stanford Law Review 72 (May 2020): 155-64.

${ }^{49}$ Nina A. Kohn, "Elder (In) Justice: A Critique of the Criminalization of Elder Abuse," American Criminal Law Review 49, no. 1 (September 2012): 1-29.
} 
rights. In some cases, women may lose their children because they are seen as negligent in protecting children from dangerous partners. Thus, the main concern in pursuing legal assistance should place attention on the protection of victims and children, as well as prevention and / or rehabilitation efforts for spouse as perpetrators, by placing punishment not as a priority. Generally, the law only emphasizes the short-term protection of women. The gender-based legal paradigm should be able to promote longterm security, including economic security, health, housing, to support the resilience and sustainability of life. ${ }^{50}$

Legal positivism tends to divide violence and women's inequality from the socio-cultural and socio-historical contexts. In this point of view, the legal arrangements for violence and inequality experienced by women will be trapped in 2 tendencies. The first tendency is to place the issue of violence occurring in the private sphere as a sporadic criminal act without considering women structural inequality. In this context, the legal construction shows negligence of structural analysis on women's gender roles, on the contrary involving certain prejudiced inclination that are racial and ethnic subordination, or cultural construction and practices regarding women's gender roles.

The second tendency is influenced by the discourse of public and private sphere distinction. The concept of private sphere in liberalism refers to activities and / or actions that are confidential and free from the intervention of elements of public. Therefore basically a liberal thought of private sphere is something that should not be regulated by law. ${ }^{51}$ Personal affairs, sexuality and reproduction, family are elements that sustain the formation of private sphere which are socially identified as spaces of women responsibility. The concept of division is in parallel with the differentiation of women and men gender roles that have been socio-culturally constructed. The public sphere is seen as realm of productive activity that are competitive, stressful so appropriate for men to struggle in creating a history of civilization. Private sphere is a realm of domestic activities that deal with procreation and as women main-duties, who are stigmatized as emotional, painstaking, affectionate, gentle, to protect and care its member in order to balance the family values.

There are a number of positivism legal system weaknesses in resolving gender-based violence that embedded in women's inequality. Firstly, legal positivism tends to view women as neutral objects. This neutrality places law as a sector that contains objectivity values and autonomous from a variety element of moral, economic, political and social, ${ }^{52}$ even though it is adopting existing rights by changing the status of social rights into legal rights. ${ }^{53}$ Secondly, the legal system tends to prioritize penalties, especially detention in solving the complexity of legal issues. Thirdly, in the context of violence against women,

\footnotetext{
50 Caroline Bettinger-Lopez, "Human Rights at Home: Domestic Violence as a Human Rights Violation," Columbia Human Rights Law Review 40, no. 1 (November 2008): 19-77.

51 Katherine O' Donovan, "Sexual Division in Law," in Sourcebook on Feminist Jurisprudence, ed. Hilaire Barnett (Great Britain: Cavendish Publishing, 1997), 156.

52 Margot Stubbs, "Feminism and Legal Positivism," in Feminist Legal Theory, ed. D. Kelly Weisberg (Philadelphia: Temple University Press, 1986), 455.

53 Chen, Chao-Ju, "Catharine A. MacKinnon and Equality Theory," in Research Handbook on Feminist Jurisprudence, ed. Robin West and Cynthia Grant Bowman (United Kingdom: Edward Elgar Publishing, 2019), 48.
} 
especially in the household, the proof method in law is charged to the plaintiff, in this case women as victims. This type of liability imposes the plaintiff to prove the defendant's mistakes. This proof method is burdensome since domestic violence is a traumatic experience that can result adverse effect on physical and mental health, as well as others detrimental consequences for survivors. Fourth, the tendency to impose the complexity of social problems as the personal or individual fault. ${ }^{54}$

The inequality construction adopted by law is part of the cultural superstructure which is built on a foundation of biological differences. This idea of biological determinism, that all human behavior determined by biological attributes, assumes biological differences as factors that influence differences in the capabilities and roles of gender in society, although many medical studies of gender identity have successfully refuted the concept. ${ }^{55}$ The most crucial from biological determinism concept is the impact on social perception and the consequences on the perpetuation of law formation. ${ }^{56}$ It can be understood that there is a dialectical processes within social, political, economic, cultural and legal structures in creating and supporting the running of a system. The immanence embedded in the legal role of analyzing the gender order has contributed to the formation of individual consciousness. The form manifested is influenced by certain historical and cultural backgrounds, yet accepted as neutral in the expressed values. In addition, the external aspects of law are reflected in the legal institutions and law enforcers that contain the compelling force to constraint an irresistible urge to behave. This aspect shapes legal influence and legal response to society. The generally accepted theory is that the law adapts and reflects shared social values. This ignores the active part played by law in shaping the perceptions of the values. ${ }^{57}$ The law is part of the entire order forming a contradictory totality, yet at the same time structuring the unity of the system. On the other word, Sexism is adapted in law, where the substance of the legal category has ignored women concerns.

On the other hand, law can be an instrument to promote the development of women's equality. Law can transform draft policy into national bills concreted in national action plan by funneling legal protection for women from the impacts of the pandemic outbreaks. Law, as a knowledge system, is a discourse that has the ability to refute or ignore and as well as perpetuate an alternative discourse to place an awareness in a particular space. The law can redefine the parameters of new relationships and therefore broaden the reach of increasingly intimate sphere by combining disciplinary methods in the form of preventive supervision and conventional repressive forms. This emphasizes the potential ability to create new social relations and new areas of legal regulation, even in private areas that have restricted reached by the law. ${ }^{58}$

\footnotetext{
54 Doris Buss, "Performing Legal Order: Some Feminist Thoughts on International Criminal Law," International Criminal Law Review 11, no. 3 (August 2011): 409-23.

55 O’Donovan, "in Law", 150.

56 O’Donovan, "in Law", 148.

57 O’Donovan, "in Law", 158.

${ }^{58}$ Carol Smart, "Feminism and the Power of Law," in Sourcebook on Feminist Jurisprudence, ed. Hilaire Barnett (Great Britain: Cavendish Publishing, 1997), 81.
} 
The legal paradigm as a legitimized method in resolving social conflicts must be analyzed comprehensively to discover the root of the issues on the gender inequality symbol reflected by the law. This is done to take advantage from the law as a tool to accommodate the interests of marginalized women and reconstruct a fair and equal gender awareness. ${ }^{59}$ The women's legal justice discourse stands on 2 point of views. Firstly, maintaining the status quo because of the law reforms will disadvantage women. Secondly, utilizing and empowering the law to create representation of women's interests. ${ }^{60}$ In the second point of view, the theory and practice of women's legal justice form interrelationships that affect each other. Social practices and phenomena construct the theoretical concepts and in the next stage dialectically complete the implementation of law at the practical level. This second view is the purposes of feminist legal theory.

$=$ The strength of the law lies in its potential to divert public awareness by framing an issue into a legal issue and setting a precedent of truth through constitutional interpretation. Thus, in realizing women's representation in the legal order as an effort to prevent women's vulnerability in dealing with various crises, feminist legal theory can be adopted to analyze the differences in the impact of this co-19 pandemic on women based on specific categories. For example, the problems experienced by informal workers, most of those have a restricted access to social security guarantees from the government in the crisis, are issues that plague most developing countries. About $70 \%$ of total employment in developing countries is the informal sector, which is equivalent to $2 / 3$ of the total workforce. ${ }^{61}$ This means that most of those in developing countries, both men and women, and their families are middle-lower class who are vulnerable to the impact of the crisis. This fact reinforces the thought of an anti-essentialist approach of feminist legal theory that resist the concept of monolithic category and singular experience. ${ }^{62}$

Anti-essentialists, also called intersectionality, originated from criticism of legal doctrines that based on a restricting approach in the formation and / or identification of subjects. This concept is used to study the interaction of multi-sector power structures in producing social inequalities that affect groups and / or individuals differently in society and formally manifested in legislation. At the same time, this concept also offers systemic and structural analysis by recognizing the variability, fluidity, and possible specific manifestations of subordination. ${ }^{63}$ Feminist legal theory of anti-essentialist recognizes the existence of multiplicity subordination and resists to be trapped in the silencing of identities that embrace a restricted vision of commonality. ${ }^{64}$ This concept is intended to

59 Rifkin, "Law and Patriarchy," 23.

60 Smart, "Power of Law," 82.

${ }^{61}$ C.P. Chandrasekhar and Jayati Ghosh, "Informal Worker in the Time of Coronavirus," International Development Economics Associates, last modified March 24, 2020, http://www.networkideas.org/ featured-articles/2020/03/informal-workers-in-the-time-of-coronavirus/.

62 Angela P. Harris, "Race and Essentialism in Feminist Legal Theory," in Sourcebook on Feminist Jurisprudence, ed. Hilaire Barnett (Great Britain: Cavendish Publishing, 1997), 250.

${ }^{63}$ Sumi Cho, "Post Intersectionality: The Curious Reception of Intersectionality in Legal Scholarship," Du Bois Review 10, no. 2 (January 2013): 385-404.

64 Darren Lenard Hutchinson, "Identity Crisis: Intersectionality, Multidimensionality, and the Development of an Adequate Theory of Subordination," Michigan Journal of Race and Law 6, no. 2 (Spring 2001): 285-317. 
provide a complete understanding of the assorted forms of subordination and discrimination experienced by women. This is required to guarantee legal protection for women across the intersection of race, class, sexuality, ethnicity, class, etc. ${ }^{65}$

Law and policy always assume women in the stereotypes as homogeneous victims and ignore the complexity of women's individual lives. Women's experiences are generalized and adopted to develop general category stereotypes to ensure legal certainty. This stereotype that establishes formal equality concept has the potential to exclude women who are beyond the general paradigm category. ${ }^{66}$ The issue emerges from the formal equality concept is the reduction of the meaning of equality into the concept of sameness of treatment or prohibition of discrimination. Indeed, formal equality can be used to cope with specific situations of discrimination, but unsuccessful to provide protection against other forms of subordination and discrimination based on certain categories that require heightened judicial scrutiny. ${ }^{67}$

The complexity of women experiences in shaping the totality is impossible to be reduced by the concept of "commonality". Injustice and violence against women is beyond the acts of violence itself, which have different goals, aspirations, concerns and priorities. ${ }^{68}$ Every woman has different experiences and identities based on race, economic class, ethnicity, cultural differences, skin color and other characteristics. ${ }^{69}$ Specific categories of women based on race particular economic classes will determine their accessibility to justice system facilities and other legal assistance in seeking justice.

A complex sexism and monolithic legal landscape are an instrument in perpetuating an unequal social structure and ultimately exacerbates the vulnerability of marginalized women in dealing with the effects of the co-19 pandemic. It is increasingly obvious that policies such as lock-down and / or social distancing are ineffective when working and living conditions make it impossible to maximize the implementation of these policies. The solution is that the root causes of women's vulnerability in dealing with a pandemic crisis must be reduced and resolved. ${ }^{70}$

One of the purposes of the law is to protect the vulnerable citizens to balance unequal legal standing. Legal provisions must ensure the achievement compiled in the legal guarantees for marginalized women justice and provide legal tools in realizing women legal justice ideals and values. ${ }^{71}$ Thus the solution is to refocus and reconstruct a sexist and monolithic legal system with legal policies that are accommodating towards

65 Verna L. Williams, Kristin Kalsem, "Social Justice Feminism," UCLA Women's Law Journal 18, no. 1 (2010): 132-93.

66 Leigh Goodmark, "Reframing Domestic Violence Law and Policy: An Anti-Essentialist Proposal," Washington University Journal of Law and Policy 3, no. 1 (2009): 41-56.

67 Martha Albertson Fineman, "The Vulnerable Subject: Anchoring Equality in the Human Condition," Yale Journal of Law \& Feminism 20, no. 1 (2008): 1-23.

68 Goodmark, "Anti-Essentialist Proposal," 47.

69 Levit, Nancy, Robert R.M. Verchick, and Martha Minow, Feminist Legal Theory: A Primer (New York: New York University Press, 2016), 25.

70 Goodmark, "Anti-Essentialist Proposal," 46.

71 Larysa Sumna et.al, "Role of Legal Profession in the Implementation of the Civil Society Human Rights," Journal of Legal, Ethical and Regulatory Issues 22, special issue 1 (2019): 1-6. 
particular interests of marginalized women. The law is expected to be able to overcome violence by concerning the particular contexts, issues, categories, and experiences of marginalized women's lives. Formulating and framing legal policies in this case will refocus the law around the diversity of women that need legal protection. In this context the law is formed by taking into account the unique characteristics based on the interests of subjected women. ${ }^{72}$

In terms of reconstruct and reform the negative impacts, as well as reanalysis the solutions in realizing women legal justice to reduce the negative causes and impacts of covid-19 pandemic outbreak, feminist legal theory approach results in 3 solution methods The solution methods aim to build public awareness about evaluating truth construction, remove legal and non-legal barriers and / or take advantage of the law to ensure equal and adequate access for women to reduce the impact of the vulnerability of economic structures and social construction. ${ }^{73}$

Firstly, analyzing the legal methods in giving gender implications and perpetuating women's subordination. It is pivotal to analyze cultural assumptions regarding women's role in society in influencing perception, human behavior, as well as legal perception as part of legal reform process. These cultural assumptions analyses can reveal cohesive pressures and impacts to challenge inequality legal decisions in demanding for integrated change. ${ }^{74}$

Secondly, making gender the main category in conducting legal analysis. This method is carried out on the basis of the consideration that the existing legal doctrines and theories are based on values from the social construction of gender inequality structures and are inadequate in accommodating women's interests. ${ }^{75}$ There are 2 ways to be done related to this method. Firstly, including a gender perspective as a compartment in the formulation of each legal regulation. This gender perspective compartment is carried out by involving women from multi-sectors representatively in the formulation of the Covid19 response policy and legal regulation, as well as others decision-making processes. Secondly, integrating gender-based violence prevention efforts into the Covid-19 response plan. These efforts include the provision of an ad-hoc network for handling gender-based violence in the midst of the co-19 pandemic by involving governments, non-governmental organizations, civil society, and other stakeholders. ${ }^{76}$

Thirdly, considering women specificity in achieving legal equality for women. It is due to multiple sources of women specific inequalities based on experience, racial hierarchy, social construction, economic differences, etc. Gender neutrality can reach achievements with certain strategies in some situations, but it is only a preliminary strategy due to the

\footnotetext{
72 Sunma et al., "Human Rights."

73 Cyntia Grant Bowman, Elizabeth M.Schneider, "Feminist Legal Theory, Feminist Lawmaking, and the Legal Profession," Fordham Law Review 67, no. 2 (1998): 249-72.

74 Vicki Schultz, "Taking Sex Discrimination Seriously," Denver University Law Review 91, no. 5 (June 2015): 995-1118.

${ }^{75}$ Katharine T. Bartlett, "Feminist Legal Methods," in Feminist Legal Theory: Reading in Law and Gender, ed. Katharine T. Bartlett \& Rosanne Kennedy (USA: Routledge, 2018), 370.

${ }^{76}$ Social Affairs, including Microfinance, 13.
} 
multiple standards and strategies in the analysis of anti-essentialism perspective. ${ }^{77}$ The strategies for achieving women's legal justice must recognize differences in women's experiences, needs and priorities since women inequality intersects with class hierarchy, economy differences, ethnic or racial bias. ${ }^{78}$ In this context, it requires legal policy to ensure the provision and access of facilities and infrastructure. It provides a foundation for the ability of women from the lower middle class to comply the policy to prevent the outbreaks of the Covid-19 pandemic. Legal policies in this context include policies that allow marginalized women and their families to survive amid the risk of losing their jobs, for example through providing social security guarantees. ${ }^{79}$ It is also included the policy in providing legal protection for women informal workers such as domestic workers that has not been stipulated in any legal regulation.

\section{Conclusion}

Using Feminist Legal Theory, this article has highlighted the impacts of Covid-19 pandemic on women's vulnerability. The outbreak of the Pandemic Covid-19 has deepened and exposed the interconnected economic, social and political crises. It also reflects the existence of established values and order that have been unequal, especially against the most marginalized communities, including women. There are 2 (two) main causes of women's vulnerability in dealing with the covid-19 pandemic. Firstly, Economic unrest is undoubtedly a gender issue amid the Covid-19 pandemic. Generally informal jobs that mostly occupied by women are associated with public spaces and social interaction have been experiencing significant economic impacts and the consequent loss of income to sustain their living. Secondly, women's vulnerability due to stigmatized gender identity. It exacerbates the stigma of women as "objects" in lieu of resentment, disappointment, and frustration due to the co-19 pandemic and its derivative impacts in the form of economic crises, increased unemployment, limited access to social security, and increased poverty.

Based on Feminist Legal Theory approach, there are 3 solution methods that can be implemented to realize women's legal justice. Firstly, analyzing the legal methods in giving gender implications and perpetuating women's subordination. Secondly, making gender as the main category in conducting legal analysis. There are 2 ways that can be done related to this method. The first is carried out by involving women in multi-sectors representatively in the formulation of the Covid-19 policy response and others decisionmaking processes. The second is integrating efforts gender-based violence prevention in the Covid-19 response plan. Thirdly, considering gender specificity in achieving legal equality for women. In this context it requires a legal policy that allows marginalized women and their families to survive amid the risk of losing their jobs, for example the provision of social security guarantees and legal protection for women informal workers, especially domestic workers.

\footnotetext{
77 Nancy E Dowd, "Masculinities and Feminist Legal Theory," Wisconsin Journal of Law, Gender, and Society 23, no. 2 (Fall 2008): 201-48.

78 Social Affairs, including Microfinance, 7.

${ }^{79}$ Chandrasekhar, "Time of Coronavirus."
} 


\section{References}

Asia Pasific Forum on Women, Law, and Development. "Covid-19 Highlights the Failure of Neoliberal Capitalism: We Need Feminist Global Solidarity." Last modified March 25, 2020. http://apwld.org/covid-19-highlights-the-failure-of-neoliberal-capitalismwe-need-feminist-global-solidarity/.

Barnett, Hilaire, ed. Sourcebook on Feminist Jurisprudence. Great Britain: Cavendish Publishing, 1997.

Bartlett, Katharine T., and Rosanne Kennedy. "Feminist Legal Methods." In Feminist Legal Theory: Reading in Law and Gender, edited by Katharine T. Bartlett \& Rosanne Kennedy, 370-403. United States of America: Routledge, 2018.

Bloodwort, Sandra. "The Roots of Sexual Violence." Marxist Left Review. Accessed May 8, 2019. https://marxistleftreview.org/articles/the-roots-of-sexual-violence/.

Bowman, Cyntia Grant, Elizabeth M.Schneider. "Feminist Legal Theory, Feminist Lawmaking, and the Legal Profession." Fordham Law Review 67, no. 2 (1998): 249-72.

Brewer, Pat. The Dispossession of Women. Chippendale: Resistance Book, 2020.

Bronin, Sara C. "What the Pandemic Can Teach Climate Attorney." Stanford Law Review 72 (May 2020): 155-64.

Buss, Doris. "Performing Legal Order: Some Feminist Thoughts on International Criminal Law." International Criminal Law Review 11, no. 3 (August 2011): 409-23.

Carli, Linda L. "Women, Gender equality and COVID-19." Gender in Management 35, no. 7 (2020): 647-655.

Chandrasekhar, C.P., Ghosh, Jayati. "Informal Worker in the Time of Coronavirus." International Development Economics Associates. Last modified March 24, 2020. http://www.networkideas.org/featured-articles/2020/03/informal-workers-in-thetime-of-coronavirus/.

Chen, Chao-Ju. "Catharine A. MacKinnon and Equality Theory." in Research Handbook on Feminist Jurisprudence, edited by Robin West and Cynthia Grant Bowman, 44-64. United Kingdom: Edward Elgar Publishing, 2019.

Cho, Sumi. "Post Intersectionality: The Curious Reception of Intersectionality in Legal Scholarship." Du Bois Review 10, no. 2 (January 2013): 385-404.

Costa, Pedro Nicolaci La. "Coronavirus Unemployment Tsunami Hitting Women Harderand It Could Cause Prolonged Damage." Forbes. Last modified April 18, 2020. https://www.forbes.com/sites/pedrodacosta/2020/04/18/coronavirusunemployment-tsunami-hitting-women-harder-and-it-could-cause-prolongeddamage/\#70ca8de95dd7.

Devlin, Hannah. "Early Men and Women Were Equal, Say Scientists." The Guardian. Last modified May 14, 2015. https://www.theguardian.com/science/2015/may/14/earlymen -women-equal-scientists. 
Dowd, Nancy E. "Masculinities and Feminist Legal Theory." Wisconsin Journal of Law, Gender, and Society 23, no. 2 (Fall 2008): 201-248.

Engels, Frederick. Asal-Usul Keluarga, Kepemilikan Pribadi, dan Negara. Jakarta: Kalyanamitra, 2004.

Fineman, Martha Albertson. "The Vulnerable Subject: Anchoring Equality in the Human Condition." Yale Journal of Law \& Feminism 20, no. 1 (2008): 1-23.

Galloti, Maria. "Migrant Domestic Workers Across the World : Global and Regional Estimates." Accessed April 30, 2020. https://www.ilo.org/wcmsp5/groups/public/--ed protect/---protrav/---migrant/documents/briefingnote/wcms 490162.pdf.

Goodmark, Leigh. "Reframing Domestic Violence Law and Policy: An Anti-Essentialist Proposal." Washington University Journal of Law and Policy 3, no. 1 (2009): 41-56.

Hamdi, Fairooz Mustafa. "The Impact of Globalization in Developing Country." Developing Country Studies 3, no. 11 (2013): 142-44.

Harris, Angela P. "Race and Essentialism in Feminist Legal Theory." In Sourcebook on Feminist Jurisprudence, edited by Hilaire Barnett, 249-255. Great Britain: Cavendish Publishing, 1997.

Harris, Nigel. The End of Third World: Newly Industrializing Countries and the Decline of an Ideology. Harmondsworth: Penguin, 1986.

Harvey, David. Imperialisme Baru. Yogyakarta: Resist Book, 2010.

Horsley, Scott. "Women are losing more job in coronavirus shutdowns." National Public Radio. Last modified April 8, 2020. https://www.npr.org/2020/04/08/829141182/women-are-losing-more-jobs-incoronavirus-shutdowns.

Hutchinson, Darren Lenard. "Identity Crisis: Intersectionality, Multidimensionality, and the Development of an Adequate Theory of Subordination." Michigan Journal of Race and Law 6, no. 2 (Spring 2001): 285-317.

International Labor Organization. "Covid-19 and the World of Work : Impact and Policy Responses." Last modified March 18, 2020. https://www.ilo.org/wcmsp5/groups/public/---dgreports/--dcomm/documents/briefingnote/wcms 738753.pdf

International Labor Organization. "The Women at Work Initiative." Accessed May 5, 2020. https://www.ilo.org/global/about-theilo/history/centenary/WCMS_480301/lang--en/index.htm.

International Labor Organization. World Employment Social Outlook: Trend for Women 2018-Global Snapshot. Geneva: International Labor Office, 2018. https://www.ilo.org/wcmsp5/groups/public/---dgreports/---dcomm/--publ/documents/publication/wcms_619577.pdf.

Johnson, Margareth E. "Changing Course in the Anti-Domestic Violence Legal Movement: From Safety to Security." Villanova Law Review 60, no. 1 (2015): 145-202. 
Kemenpppa. "Perempuan Rentan Jadi Korban KDRT, Kenali Faktor Penyebabnya." Last modified May 19, 2018. https://www.kemenpppa.go.id/index.php/ page/read/31/1742/perempuan-rentan-jadi-korban-kdrt-kenali-faktorpenyebabnya.

Kohn, Nina A. "Elder (In) Justice: A Critique of the Criminalization of Elder Abuse." American Criminal Law Review 49, no. 1 (September 2012): 1-29.

Kompas. "Bank Dunia Kucurkan Pinjaman 700 Juta Dollar AS untuk Indonesia." Last modified May 17, 2020. http://money.kompas.com/read/2020/05/17/ 160100526/bank-dunia-kucurkan-pinjaman-700-juta-dollar-as-untukindonesia?page $=2$.

Kusumastuti, Ayu. "Rural Infrastructure and Gender Inequality in Agribusiness Development (A Case of Batu, East Java Province, Indonesia." In food security and food safety for the twenty first century, edited by Soraj Hongladarom, 65-83. Bangkok: Department of Philosophy and Center for Ethics of Science and Technology Chulalongkorn University, 2015.

Levit, Nancy, Robert R.M. Verchick, and Martha Minow. Feminist Legal Theory: A Primer. New York: New York University Press, 2016.

Lopez, Caroline Bettinger. "Human Rights at Home: Domestic Violence as a Human Rights Violation." Columbia Human Rights Law Review 40, no. 1 (2008): 19-77.

Mittal, Shalini and Tushar Singh. "Gender-Based Violence During COVID-19 Pandemic: A Mini-Review." Frontiers in Global Women's Health 1, no. 4 (September 2020):1-7.

Neuman, Scott. "Global Lockdown Resulting in 'Horrifying Surge' in Domestic." National Public Radio. Last modified April 6, 2020. https://www.npr.org/sections/coronaviruslive-updates/2020/04/06/827908402/global-lockdowns-resulting-in-horrifyingsurge-in-domestic-violence-u-n-warns.

O’ Donovan, Katherine. "Sexual Division in Law." In Sourcebook on Feminist Jurisprudence, edited by Hilaire Barnett, 146-60. Great Britain: Cavendish Publishing, 1997.

Postmus, Judy L., Gretchen L. Hoge, Jan Breckenridge. "Economic Abuse as an Invisible Form of Domestic Violence : Multicountry Review." Trauma, Violence, \& Abuse 21, no. 2 (March 2018): 261-83.

Power, Kate. "The COVID-19 pandemic has increased the care burden of women and families." Sustainability: Science, Practice and Policy 16, no. 1 (2020): 67-73.

Prado, Mariana Mota. "What is Law and Development?." Revista Argentina de Teoria Juridica 11, no. 1 (August 2010): 1-20.

Prizzia, Ross. "An International Perspective of Privatization and Women Workers." Journal of International Women's Studies 7, no. 1 (November 2005): 55-68.

Rifkin, Janet. "Toward A Theory of Law and Patriarchy." In Source Book on Feminist Jurisprudence, edited by Hilaire Barnett, 23-25. Great Britain: Cavendish Publishing, 1997. 
Schimidt, Samantha. "Women Have Been Hit Hardest by Job Losses in The Pandemic and It May Only Get Worse." Last modified May 9, 2020. https://www.washingtonpost.com/dc-md-va/2020/05/09/women-unemploymentjobless-coronavirus/.

Schultz, Vicki. "Taking Sex Discrimination Seriously." Denver University Law Review 91, no.5 (June 2015): 995-1118.

Smart, Carol. "Feminism and the Power of Law." In Sourcebook on Feminist Jurisprudence, edited by Hilaire Barnett, 81-83. Great Britain: Cavendish Publishing, 1997.

Strange, Susan. "The New World of Debt." New Left Review 230, no. 1 (August 1998): 91114.

Stubbs, Margot. "Feminism and Legal Positivism." In Feminist Legal Theory, edited by D. Kelly Weisberg, 454-75. Philadelphia: Temple University Press, 1986.

Sumna, Larysa., Olexii Yermak, Kateryna Denysenko, Ihor Bodnar, Julia Zaliskaya. "Role of Legal Profession in the Implementation of the Civil Society Human Rights." Journal of Legal, Ethical and Regulatory Issues 22, special issue 1 (2019): 1-6.

Tarigan, Muhammad Insan, and Raisha Hafandi. "Equal Access to the Vaccination of Covid-19 in Southeast Asia: Can ASEAN be a Catalyst?" Hasanuddin Law Review 7, no. 2 (2021): 119-132.

Taub, Amanda. "A new Covid-19 Crisis: Domestic Abuse Rises Worldwide." The New York Time News. Last modified April 6, 2020. https://www.nytimes.com/2020/04/06/ world/coronavirus-domestic-violence.html.

The Economist. "The Pandemic Maybe Making Domestic Abuse Worse." Last modified May 9, 2020. https://www.economist.com/international/2020/05/09/the-pandemicmay-be-making-domestic-abuse-worse.

United Nation Department of Economic and Social Affairs. 2009 World Survey on The Role of Women in Development: Women's Control Over Economic Resources and Access to Financial Resources including Microfinance. New York: United Nation Publication, 2009.https://www.unwomen.org/sites/default/files/Headquarters/Media/Publicatio ns/UN/en/WorldSurvey2009.pdf.

Veltmeyer, Henry, James Petras, and Steve Vieux. Neoliberalism and Class Conflict in Latin America: A Comparative Perspective on the Political Economy of Structural Adjustment. London: Macmillan Press, 1997.

Williams, Verna L., Kristin Kalsem. "Social Justice Feminism." UCLA Women's Law Journal 18, no. 1 (2010): 132-93.

Conflict of Interest Statement: The author(s) declares that the research was conducted in the absence of any commercial or financial relationship that could be construed as a potential conflict of interest.

Copyright: (C) HALREV. This is an open access article distributed under the terms of the Creative Commons Attribution 4.0 International License (CC-BY 4.0), which permits unrestricted use, distribution, and reproduction in any medium, provided the original author and source are credited.

Hasanuddin Law Review (Hasanuddin Law Rev. - HALREV) is an open access and peer-reviewed journal published by Faculty of Law, Hasanuddin University, Indonesia. 